\title{
Sculpting in Mind: A Search for Meaning Wen-Shu Lai
}

During my five-year study (1991-1995) in the art school of the University of lowa, I was constantly engaged in one project. The project started with an assignment in the class, Basic Design. It was to transform a four-by-four-inch paper into a three dimensional object by one cut and one piece of tape. After the assignment was finished, my curiosity about the potential of a piece of paper compelled me to continue this project. At that time, I did not know what a piece of paper could do or where it would lead me. As I went along, I realized that I could make interrelated structures and spaces in a single sheet of paper by cutting, folding, and bending. Based on this concept, I made about forty pieces of sculptures within two years.

After two years of intensive exploration of the possibilities that a sheet of paper could have, the humble material, paper, and the methods, cutting, folding, and bending, which I used to create my works, became my obstacles to move one step further. As my life changed in those two years, the way I saw art changed too. I felt strongly that something was missing in my sculpture besides its form, space, structure, and beauty. Something deep in my mind was missing in my sculpture but I couldn't name it at that time. I asked myself, "Why limit my works within the transformation of a single sheet of paper from two to three dimensions? What meaning do I really want to convey to the viewers in my sculpture?" I felt that I needed to escape from those limitations so I could approach my art from a different perspective. Without knowing what direction I was heading to, I felt anxious and uncertain about myself and my art.

Later on, Plexiglas as a new medium was used for my sculptures. By using sandpaper to create the translucent patterns on the surface of the sculpture, the transparent Plexiglas gave a very interesting effect to the sculpture. The translucent and transparent qualities of the Plexiglas and the phenomenon of reflection made the sculpture look like an illusion. But, the novelty of material can't give new meaning to a work, only the artist can. After I got it done, I still felt uncertain about my work. I asked myself, "Is that enough? Is that all?" I did not know what I really wanted to say in this Plexiglas sculpture. I asked myself the same question that Ben Shahn asked himself, "This may be art, but is it my own art?" (1957, p.35).

Several months later, I married. One year later, my father had a stroke and lost his abilities to walk and talk. The following year, my son Peter was born. The dramatic changes in my life made me meditate my own identity between the roles I play: a wife, a daughter, a mother, and an artist. Naturally, instead of making more sculptures in abstract forms, I began a series of portraits of myself and my father in photos. Most of the images were related to human pain, fear, and struggle in a symbolic way--a reflection of my inner world at that time.

During this period of time, the Plexiglas sculpture I had previously made happened to be placed on a stool directly in front of the wall of my living room. 
Because its surface was sanded to emphasize the designs, the light from the window passing through the sculpture cast a shadow of varying amounts of light on the wall. The shadow had all the fine, delicate details and textures of the sculpture. As time passed by, the form and position of the shadow changed and shifted little by little until the sun went down. In the night, the shadow appeared again as soon as the light was turned on.

One morning, as I was watching the shadow of my sculpture on the wall, a thought came to my mind: The traces of the shadow are also the traces of time, particularly, the traces of the time that I spent here in the past five years (it took me five years to bring this sculpture-shadow into being). But, my life did not begin five years ago and end at this moment. It's still in process. From the four-by-four-inch paper to this sculpture-shadow I saw on the wall, the process told me one thing: my artistic serial is an ongoing project which is a dialogue back and forth between myself, my life and the work itself. I can never know when this ontological interpretation of being in the world begins and where it ends. I am on my way forever.

I set up my slide projector in front of my sculpture and projected the image on the slide, my hometown, llan, in Taiwan, onto to the wall. The image overlapped with my sculpture's shadow. The stories deep in my mind about my childhood and families in Taiwan came alive and merged with my present life. The shadow of my sculpture and the image of my hometown, an illusion based on a distant reality, appeared and transmitted the messages about the ambiguity of time, space, and reality. At that moment, I experienced what Ben Shahn said, "I can follow them (the imagery) backward at least to that point at which they disappear into the limbo of the subconscious, or the unconscious, or the instinctive, or the merely biological" (1957, p.33).

I came to realize that my interpretation of my art and the meaning I wanted to convey through it would change from time to time as my life kept evolving. The meaning of the work will be shaped, revised and recreated by the artist's and the viewers' stories rather than accepted unthinkirgly.

Art is more of a process than a final product. It is a dialectic between critical reflection and action which is impelled by the inner critic within the artist. As I reflect back now, I realize that my questioning, uncertainty, and anxiety about myself and my art are the forces which make me reflect and act, and bring myself and my art into being. "Artists have no choice but to express their lives. They have only, and that not always, a choice of process. This process does not change the essential content of their work in art, which can only be their life" (Truitt, 1982, p 43). Ben Shahn said:

An artist at work upon a painting must be two people, not one. He must function and act as two people all the time and in several ways. On the one hand, the artist is the imaginer and the producer. But he is also the critic... the critic is constantly objecting, constantly chiding, holding the hand back to image alone, so that the painting remains 
only that, so that it does not split into two things, one, the image, and another, the meaning. (1957, p.34)

It is through the process of acceptance and rejection, the alternating of doing and reflecting, the artist is moving toward some realization of who he is and what he wants to be. The inner critic within the artist is the shaping force. "A man becomes his attentions... His observations and curiosity, they make and remake him" (Least Heat Moon, 1982, p.17).

Marilyn Zurmuehlen's philosophies--art as praxis, art as symbol, and art as presence--are based on Kenneth Beittel's three essential conditions for making art. They have a great influence on me as an artist and as an art educator. My experience of making art that I discussed at the beginning of this paper demonstrated concretely that in a situation of making art, an artist could be an originator, a transformer, and a reclaimer. By generative praxis, I realize my reflection upon my personal story is the crucial key to establishing essential conditions for making art.

\section{Beittel's Three Essential Conditions for Making Art}

"Art work is made, brought into being, through an expressive act" (Zurmuehlen, 1990, p.3). Beittle defined the act as "where conversion from unreflective to reflective thought comes about" $(1973$, p.56). He identified artistic causality, idiosyncratic meaning, and intentional symbolization as the three essential conditions for making art. "First the making, then the naming, and then seeing is forgetting the name of the thing one sees are emblematic of [these] three philosophies that are a grounding for contemporary studio art" (Zurmuehlen, 1990, p.6). They often exist simultaneously although each conception distinctively illuminates particular aspects of art.

\section{Artistic Causality}

The first condition of Beittel's three essential conditions for art making is artistic causality. It is a situation where an artist feels like an originator. The artist is not merely doing something with art materials. He turns doing into making through his reflective thought. It means that a dialogue between an artist and his art work is present in this condition. It's strongly related to Zurmuehlen's philosophy, art as praxis - I am what I make. I would like to discuss these concepts through the story of my son's art making.

This past summer, my three-and-a-half-year-old son Peter experienced a tornado for the first time in his life. He took shelter in the dark basement of the day care center he attended. He witnessed broken trees, and torn roofs of our apartment in lowa City. Since then, tornadoes have become something that concerns him very much.

One day, we saw a tornado sculpture outside the Studiolo Gallery on Gilbert Street. "Look, Peter. It's a tornado sculpture," I told him. He hesitated for a few seconds. Then, he grasped one of my hands tightly and walked toward the 
eight-foot-high tornado sculpture. Even though he had an ambivalent expression on his face, he touched the sculpture, smiled and said, "Mom, It's a tornado." I guessed what he perceived was not the physical appearance of the wire-made tornado sculpture, but a particular tornado he experienced that summer.

I don't remember when it began, but Peter has repeatedly used a spiral image as a representation of tornadoes. Many times he drew scenes with houses and animals which were carried away by tornadoes.

One day, I used Scotch tape to put Peter's drawings, paintings and craft projects on the wall, so he could look at them and add things on. "Mom, let me do it." Peter took over the job and I left. I returned in fifteen minutes and found that Peter had covered one of his works all over with the tape I gave him. It is a piece of paper with a cut-out umbrella shape on it. I had no clue what he was doing, so I asked him, "Peter, what happened to your umbrella?" He replied, "My umbrella was to n by the tom. acio. I arn fixing it with m.... Scotch tape."

Earlier Peter had made an umbrella like the other children at the day care center. His teacher had helped him trace the outline of an umbrella from a template, cut it, and glue it onto a piece of paper. This ordinary umbrella became a unique one when he gave meaning to it. As he covered the umbrella with tape bit by bit on his own, he thought about not only the tornado which visited lowa City not long ago, but also the broken tree and torn roof it left us. An idea came to him about what the cut-out umbrella and the Scotch tape might be, and then, it started clarifying itself to him through his praxis.

Peter's doing subtly shifted into making. It's very common that an artist starts with an idea and often ends up with something entirely different. In Stein's words, "As I go along, the painting changes, and I have to change with it or else the painting will fail" (1986, p.62). This is exactly what Peter experienced from cutting out an umbrella shape, covering it with tape, and finally reaching the realization that he was fixing an umbrella torn by a tornado. Beittel defined this condition for art making as artistic causality which is clossly, tied to the philosophy of praxis.

One rainy afternoon, Peter was lying in his bed for a nap. He watched the rain outside the window. "Mom, I need the umbrella to keep me dry. It's raining." He insisted that our roof which was slightly damaged by the tornado would leak soon. I brought an umbrella to his bed. He lay underneath it and finally fell asleep. By fixing the cut-out umbrella with Scotch tape and sleeping underneath an umbrella, Peter integrates two kinds of praxis in his life. He is what he does, he is what he makes.

\section{Idiosyncratic Meaning}

The second essential condition is idiosyncratic, the affective image-bound meaning which is uniquely bound to a person and situation. "This situational uniqueness closely ties to the philosophy of art as presence" (Zurmuehlen, 1990, p.25). 
"The first thing that we do with images is to envisage a story" (Langer, 1951, p.128). Peter's cut-out umbrella which was covered up by Scotch tape represents something other than its physical appearance. "What it represents is intended by the maker; what is shared between maker and viewer is the intended representation; and verbal language elucidates the meaning of what is represented" (Zurmuehlen, 1990, p.1). I realized that Peter's life experience was symbolically transformed by his mind when he told me: "My umbrella was torn by the tornado. I am fixing it with my Scotch Tape." The image he worked on had a unique meaning bound to him and to the particular situation he had been through in the past summer. The expression of such meaning impels and guides Peter's art making. Through the expressive act, he transformed the unique meaning into symbol. In other words, he is a transformer.

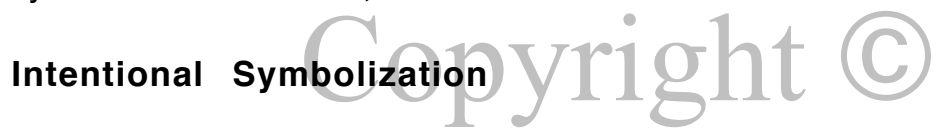

The third condition of Beittel's three essential conditions for art making is intentional symbolization, "the artist's desire to work over into materials some equivalent of idiosyncratic meaning." This condition is related to Zurmuehlen's philosophy--art as symbol.

Sometimes, Peter lies down on the floor and holds one of my legs when he wants to stop me doing my housework. So, I have to drag him around if I want to get things done. One day, Peter was bored and alone when I was washing dishes. Instead of holding my leg and asking me to stop washing dishes, he came up to me with his stuffed toy rabbit and said, "Mom, look. My rabbit loves me so much, he is holding my leg and won't let me go." Peter had put one of his legs in his rabbit's joined arms. I stopped washing dishes and looked at him. Oh, dear, my sweet little son was walking in circles, showing me how the rabbit was dragged around with him. "Mom, have you seen that? He just won't let go," he repeated again. Then, he walked toward his drawing table and put his rabbit on top of it. He sat down and began to draw. He raised his head and asked his rabbit from time to time: "Do you like this picture? No? I can draw you another one."

When Peter put one of his legs in his toy rabbit's joined arms, his past experience came to mind. He reflected on the unique situation between him and me in the past and decided to bring it to the present by using his stuffed rabbit as a vehicle. His action--walking in circles with a rabbit holding his leg, and his narrative, "My rabbit loves me so much that he won't let me go," symbolize our mother-and-son relationship.

It is very clear that the meaning that he tried to convey to me is: I love you very much. I want you to draw and play with me. That's why I always hold your legs and won't let you work. Through his play with his rabbit, he gave his idiosyncratic meaning a form. He reclaimed through a presentational symbol how much he loves me.

Art reaches beyond what is established. It offers us opportunities to shape our individual and collective life stories. The encounters with art can release our imagination, extend our lived experiences, and renew our understanding of 
our own, as well as others', stories. The art world is a world of interpreted things and it is a constructed world. It is open to interpretation and always under construction. The artists who are constantly searching for meaning are seekers and questioners. In the process, they try "to articulate the themes of their existence and to reflect on those themes until they know themselves to be in the world and can name what has been up to then obscure" (Greene, 1978, p.18).

\section{References}

Beittel, Kenneth. (1973). Alternatives for Art Education Research. Dubuque, IA: William C. Brown.

Greene, Maxine. (1978). Landscapes of Learning. New York: Teachers College Press.

Langer S. K. (1951). Philosophy in A New Key (2nd Ed.). New York: New American Library.

Least Heat Moon, W. (1982). Blue Highways. New York: Ballantine Books.

Shahn, Ben (1957). The Shape of Content. Cambridge, Massachusetts: Harvard University Press.

Stein, H. (1986). Artists Observe. New York: Abrams.

Truitt, A. (1982). Daybook: The Journal of an Artist. New York: Penguin.

Zurmuehlen, Marilyn. (1990). Studio Art: Praxis, Symbol, Presence. Reston, Virginia: The National Art Education Association.

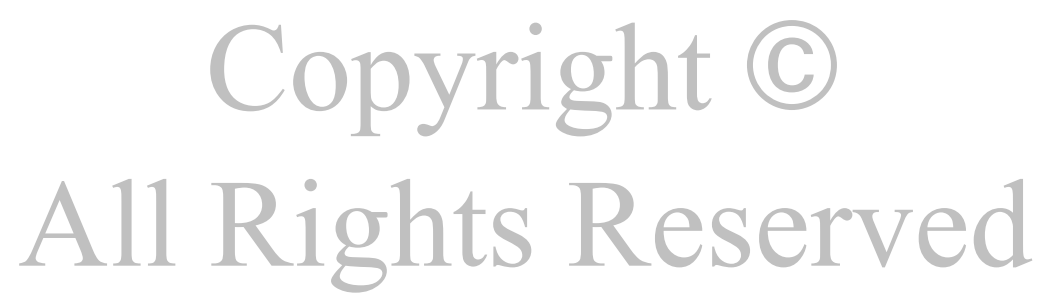

